\title{
TEACHERS' TECHNOLOGY INTEGRATION AND DISTANCE LEARNING ADOPTION AMIDST THE COVID-19 CRISIS: A REFLECTION FOR THE OPTIMISTIC FUTURE
}

\author{
Imam Fitri RAHMADI \\ ORCID: 0000-0001-5175-1187 \\ Faculty of Teacher Training and Education \\ Universitas Pamulang \\ Tangerang Selatan, INDONESIA
}

Received: 01/06/2020 Accepted: 08/09/2020

\begin{abstract}
All of a sudden, teachers and students around the globe have to deal with distance learning amidst the coronavirus disease 2019 (COVID-19) crisis. It is becoming increasingly important to understand teachers' technology integration and distance learning adoption after a sudden implementation of the working-fromhome policy as a precaution towards the further transmission of the virus. The present study examines the issues particularly regarding the used technologies, the process of distance learning, and the teachers' distance learning adoption levels. This study was conducted using an online survey involving 572 teachers in Indonesia. The results reveal that teachers tend to use devices and applications for remote instruction that already they used for daily life, and global applications are more likely chosen by teachers for managing virtual classrooms rather than the local ones. The teachers stand on an enhancement level of technology integration thus yet integrate technology as a transformation of learning. Most teachers have immediately prepared for teaching remotely when the working-from-home policy has been implemented so that they can be categorised as early adopters of distance learning. Teachers' agility in adopting distance learning during the crisis raises an optimistic signal to effectively adapt and adopt remote instruction to formal school environments in the future. Since the current study has only examined teachers in one country regardless of teaching subjects and school levels, a cross-national study on a specific subject and school level is needed in the next study.
\end{abstract}

Keywords: Teachers' technology integration, distance learning adoption, distance learning, coronavirus disease 2019 (COVID-19) crisis.

\section{INTRODUCTION}

All of a sudden, teachers and students around the globe have to deal with distance teaching and learning during the coronavirus disease 2019 (COVID-19) crisis as a consequence of a working-from-home policy to prevent further transmission of the virus. In fact, the outbreak is causing various levels of disruptions in education globally commenced with school closures in 165 countries that impact over 1.5 billion students (Doucet et al., 2020). A variety of learning approaches and strategies attempted by teachers in order to run remote learning smoothly so that the students could learn as convenient as in face-to-face learning. There is no formal preparation in advance to face this challenge; consequently, teachers were dealing with this situation by their own creativity. The students stayed away from schools and thrust into a vastly different circumstance than the one they have known. Additionally, it was inevitable for parents to get involved in the learning processes to educate their children because they are studying from home. Teaching in a tumultuous time, therefore, requires a high sense of innovativeness as well as generous flexibility to promote delightful rather than painful learning activities (Martinez-Cola et al., 2018). 
Amidst unprecedented worldwide impacts of the COVID-19, particularly toward the education sector, it is becoming increasingly important to understand teachers' technology integration and distance learning adoption after a sudden implementation of the working-from-home policy. The term technology integration means as effective use of information and communication technologies (Tondeur et al., 2009) and appropriate implementation of educational technologies to accomplish intended learning outcomes (Davies \& West, 2014). Adoption is about the individual choice to accept or reject particular innovations integrated into an appropriate context (Hall \& Khan, 2003; Straub, 2009). Furthermore, technology adoption refers to an individual consideration to reach a decision for accepting and using new technology or even rejecting the one (Sepasgozar \& Davis, 2018). The teachers' technology integration and distance learning adoption in this study thus defined as the decision and choice of teachers for conducting distance education programs by harnessing certain technologies. Generally speaking, it appears that the teachers use assorted technologies to conduct an asynchronous or synchronous remote learning from home whilst there is distinctive agility in adopting distance learning to their hand. Nevertheless, exact detail about the integrated technologies and the adoption levels in the thick of the COVID-19 outbreak remains a question.

\section{THEORETICAL BACKGROUND}

Understanding teachers' technology integration and distance learning adoption levels can be interpreted by using various frameworks including substitution, augmentation, modification, and redefinition (SAMR) model of technology integration (Puentedura, 2006), typical process of technology adoption (Prensky, 2005), technology integration matrix - TIM (Florida Center for Instructional Technology, 2019), technological pedagogical content knowledge - TPACK (Koehler \& Mishra, 2005; Mishra \& Koehler, 2006), and adoption curve (Rogers, 1962). Those frames of reference beneficial for identifying to what extent teachers adapt and adopt technologies to their hands for learning at a distance.

SAMR is a classroom technology integration framework consisting of two main levels with four different steps (Puentedura, 2006). Enhancement is the basic level that includes substitution and augmentation steps. Technology merely plays as a direct tool with minor functional improvement at this level. The advanced level is transformation containing modification and redefinition steps in which technology allows for redesign and new creation of tasks. Cencerning the process of technology adoption, it has a four-step typical process namely dabbling, doing old things in old ways, doing old things in new ways, and doing new things in new ways (Prensky, 2005). It is a gradual process that technological and societal aspects are two major factors in progressing technology adoption faster. While TIM serves as a framework for describing and targeting the use of technology to enhance instruction incorporating five interdependent characteristics of meaningful learning environments: active, collaborative, constructive, authentic, and goal-directed associated with five levels of technology integration: entry, adoption, adaptation, infusion, and transformation that apply equally to face-to-face and online learning (Florida Center for Instructional Technology, 2019).

Meanwhile, TPACK is a framework for assessing as well as developing teachers' knowledge in terms of integrating technology into learning and instruction processes that introduces relation and complexity to the basic knowledge of teaching: content, pedagogy, and technology (Cox \& Graham, 2009; Koehler \& Mishra, 2009; Koehler, Mishra, \& Cain, 2013). There are seven knowledge domains of the TPACK framework, including technological knowledge (TK), pedagogical knowledge (PK), content knowledge (CK), pedagogical content knowledge (PCK), technological content knowledge (TCK), technological pedagogical knowledge (TPK), and technological pedagogical content knowledge (TPACK). Hence, TPACK is not only a framework but a new kind of knowledge for teaching as well. Teachers or educators in general who confidently mastering TPACK may integrate technology appropriately in the classroom.

The adoption curve concept (Rogers, 1962) divides adoption rates into five levels. Each level has its own common percentage and description as follows: 1 ) innovators $(2.5 \%)=$ the first individuals to adopt an innovation who willing to take risks and have the highest social class, a great financial fund, and access to scientific sources; 2 ) early adopters $(13.5 \%)=$ the second fastest individuals to adopt an innovation who have the highest degree of opinion leadership, a higher social status, and more well-educated among the other adopter categories; 3 ) early majority $(34 \%)=$ individuals who adopt an innovation after a varying degree of time, tend to be slower in the adoption process, and have above-average social status as well as contact with 
early adopters; 4) late majority $(34 \%)=$ individuals who adopt an innovation after the average member of society has adopted the innovation, have a high degree of skepticism and below-average social status; and 5) laggards $(16 \%)=$ the last individuals to adopt an innovation who have an aversion to agents of change, likely to have the lowest social status, tend to be advanced in age, and typically focus on traditions.

\section{LITERATURE REVIEW}

Several studies have suggested that pivotal importance to study teachers' educational technology adoption in different situations. Technology adoption is a dynamic and complex societal process while cognitive, emotional, and contextual concerns should be taken into account seriously for facilitating a successful technology adoption (Straub, 2009). The different qualifications, experiences, and concerns in diverse teaching situations lead to the variation of adoption processes (Gabby et al., 2017). Besides, particular local realities such as philosophical, organisational, and political interests might also be impacting teacher's adoption decisions (Kotrlik \& Redmann, 2009). More specifically, school stakeholders play a significant role in the teacher's decisions for adopting technology (Sugar et al., 2004), they have to provide a clear message about how technology benefitting for effective classroom and affecting teacher's roles. A better understanding of what technologies are available and useful for teachers valuable to encourage educational technology integration into teaching and learning practices (Smith et al., 2018). Accordingly, investigating the way in which the teachers integrate technology and adopt distance learning in the time of uncertainty during the COVID-19 crisis is fruitful to inform key stakeholders in education to develop specific interventions for appropriate technology integration and distance learning adoption in the future.

So far, however, there has been little discussion about teacher's technology integration in the context of distance learning. Most studies in the technology integration of teachers have only been carried out in the face-to-face learning environments, in case of general technologies (Cubeles \& Riu, 2016; Perea, 2016; Merç, 2015; Ruggiero \& Mong, 2015; Vecino, 2017) or with regard to the specific one such as computer technologies (Adegbenro \& Olugbara, 2019; Wang, 2014; Budiman \& Ngadiso, 2018), mobile technologies (Wang, 2016) including tablets and smartphones (Dees et al., 2017; Fuentes \& Albertos, 2017), and other avant-garde technologies for examples robots (Rosanda \& Starcic, 2019) and 3D printing (Song, 2018). While some studies touching in the context of distance learning (Adewara \& Lawal, 2015; Dillinger, 2000; Pange et al., 2004), those merely address the teachers' attitude, perception, and interaction of technologyenhanced distance learning. In addition to the research gap, far too little attention has been paid to the study of teacher's distance learning adoptions. A number of studies focus on distance learning adoptions as an institutional movement instead of personal action by teachers. The institutional adoptions of distance learning varied from distance learning itself (Cassidy \& Lane, 1994), to blended learning (Humbert, 2007; Porter et al., 2014), e-learning (Kisanga \& Ireson, 2015; Okazaki \& Renda dos Santos, 2012; Yu et al., 2007), and m-learning (Sarrab, 2013).

\section{PURPOSE OF THE STUDY}

The present study tries to understand teachers' technology integration and distance learning adoption levels after a sudden implementation of the working-from-home policy. Accordingly, the main issues addressed in this study including technology used by teachers as tools for distance learning, the process of distance learning conducted by teachers, and teachers' distance learning adoption levels. Research questions of the study therefore are:

1. What technologies used by teachers as tools for distance learning?

2. How was the process of distance learning conducted by teachers?

3. What are the teachers' distance learning adoption levels?

The primary findings revealed that teachers integrate various devices and applications for facilitating learning to students remotely. There are common activities, tasks, and resources frequently used for learning at a distance, and the majority teachers are early adopters of distance learning. Hereinafter, this study provides discussion as well as reflection for the optimistic future. 


\section{METHOD}

The study of teachers' technology and distance learning adoption during the COVID-19 crisis is a descriptive cross-sectional research conducted in Indonesia by using an online survey. The research design was chosen because of its effectivity to collect data and study multiple outcomes at a one-time point (Levin, 2006; Wang \& Cheng, 2020). Following the research design, the survey was administered two weeks after the Indonesian Government implementing a working-from-home policy for all employees including teachers starting from 16 to 27 March 2020. In this critical situation, teachers should teach students remotely from home without any formal preparations.

A questionnaire was developed on Google Form and distributed to teachers by a convenience sampling method through a variety of social media such as WhatsApp, Facebook, and Twitter within five working days between 30 March and 3 April 2020. The questionnaire, in particular about the process of distance learning, was developed based on the revised version of Bloom's taxonomy cognitive domain (Anderson et al., 2001), learning theories of behaviorism, cognitivism, constructivism and connectivism, and the classification of learning resources (Betrus, 2008). Additionally, the teachers' reflection on the level of distance learning adoption was adopted from the Rogers's innovations adoption curve (1962). All items in the question sheet aim to measure frequency with an exception on the adoption rates.

Regarding the data analysis technique, a descriptive statistic has been utilised to simplify, analyse, and describe the main features of collected data as well as visualise the data in highly apprehensible graphs (Holcomb, 2016). As the ethical study as concerned, it was explicitly stated in advance that all collected data is used merely for research purposes and the teachers voluntarily participated in this study.

Apart from the policy prolongs to the end of the school semester, this study portrays an early experience of teachers teaching their students in the first two weeks of the working-from-home policy in Indonesia. Until this article was written in May 2020, the teachers remain to continue practicing learning and instruction at a distance by various technologies in hand.

\section{FINDINGS AND DISCUSSIONS}

After the one-week spreading, there were 572 teachers completely filled in the online questionnaire. Hereby in the table below is the detail information about teachers' profile regarding their gender, age, educational background, teaching experience, school status, and location. The technology used by teachers as tools for distance learning, the process of distance learning conducted by teachers, and the teachers' distance learning adoption levels are presented in the following sections.

Table 1. The Profile of Teachers in the Study

\begin{tabular}{llllll}
\hline Gender & Male & Female & & & \\
& 182 & 390 & & & \\
& $31.82 \%$ & $68.18 \%$ & & & \\
\hline Age & $<25$ years & $25-35$ years & $36-45$ years & $46-55$ years & $>55$ years \\
& 68 & 260 & 124 & 101 & 19 \\
& $11.89 \%$ & $45.45 \%$ & $21.68 \%$ & $17.66 \%$ & $3.32 \%$ \\
\hline Educational background & Associate & Bachelor & Master & Doctor & \\
& 8 & 471 & 87 & 6 & \\
& $1.40 \%$ & $82.34 \%$ & $15.21 \%$ & $1.05 \%$ & \\
\hline Teaching experience & $<5$ years & $5-10$ years & $11-15$ years & $16-20$ years & $>20$ years \\
& 185 & 154 & 111 & 46 & 76 \\
& $32.34 \%$ & $26.92 \%$ & $19.41 \%$ & $8.04 \%$ & $13.29 \%$ \\
\hline School level & Elementary & Middle & High & & \\
& 176 & 135 & 261 & & \\
& $30.77 \%$ & $23.60 \%$ & $45.63 \%$ & & \\
\hline
\end{tabular}




\begin{tabular}{|c|c|c|c|c|c|c|}
\hline \multirow[t]{3}{*}{ School status } & Private & \multicolumn{5}{|l|}{ Public } \\
\hline & 191 & \multicolumn{5}{|l|}{381} \\
\hline & $33.39 \%$ & \multicolumn{5}{|l|}{$66.61 \%$} \\
\hline \multirow[t]{3}{*}{ Location } & Sumatera & Java & Kalimantan & Sulawesi & Papua & Others \\
\hline & 137 & 323 & 2 & 76 & 0 & 34 \\
\hline & $23.95 \%$ & $56.47 \%$ & $0.35 \%$ & $13.29 \%$ & $0.00 \%$ & $5.94 \%$ \\
\hline
\end{tabular}

Table 1 describes the teacher's profiles participated in this study. Almost $70 \%$ of the participants are female teachers. The majority of teachers aged between 25 and 35 years reaching over $45 \%$ while teachers with the age of more than 55 years are the minority one. Additionally, the vast majority of teachers hold a bachelor degree achieving over $80 \%$. However, more than half of the teachers have experience in teaching less than 10 years. Around $45 \%$ of teachers teach at the high school level, this number is almost double compared to that of in middle school level. Meanwhile, the number of elementary school teachers is just under a third. Regarding the school status, around two-third of teachers work in public schools while the rest work in private schools. Moreover, over $50 \%$ of teachers living in Java and almost one-quarter of them living in Sumatera. Unfortunately, there were no teachers from Papua who participated in this study and merely a small number of teachers from Kalimantan and other islands.

\section{Technologies Used by Teachers for Distance Learning}

Teachers use ample technologies for conducting distance learning examined with regard to devices and purposes. The devices include computer desktop, laptop, smartphone, and tablet. Purposes of using technologies are investigated around the issues of online live teaching, communication to students, and virtual classroom organisations, which can bee seen in the table below.

Table 2. Technologies Used by Teachers for Distance Learning

\begin{tabular}{|c|c|c|c|c|}
\hline \multicolumn{5}{|l|}{ Devices } \\
\hline Desktop computers & Laptops & Smartphones & Tablets & \\
\hline 43 & 443 & 508 & 40 & \\
\hline $7.52 \%$ & $77.45 \%$ & $88.81 \%$ & $6.99 \%$ & \\
\hline \multicolumn{5}{|l|}{ Synchronous lessons } \\
\hline Facebook live & Google meet & Instagram live & Skype & Tiktok live \\
\hline 36 & 54 & 25 & 9 & 4 \\
\hline $6.29 \%$ & $9.44 \%$ & $4.37 \%$ & $1.57 \%$ & $0.70 \%$ \\
\hline WhatsApp VC & Whereby & YoutTube live & Zoom & Not teaching live \\
\hline 323 & 0 & 38 & 121 & 201 \\
\hline $56.47 \%$ & $0.00 \%$ & $6.64 \%$ & $21.15 \%$ & $35.14 \%$ \\
\hline \multicolumn{5}{|c|}{ Communication with students } \\
\hline Email & FB Messenger & Instagram & Line & Slack \\
\hline 198 & 107 & 69 & 11 & 0 \\
\hline $34.62 \%$ & $18.71 \%$ & $12.06 \%$ & $1.92 \%$ & $0.00 \%$ \\
\hline Telegram & Twitter & WeChat & WhatsApp & No communication \\
\hline 17 & 4 & 6 & 550 & 5 \\
\hline $2.97 \%$ & $0.70 \%$ & $1.05 \%$ & $96.15 \%$ & $0.87 \%$ \\
\hline \multicolumn{5}{|l|}{ Virtual classroom } \\
\hline Brainly & Edmodo & Google Classroom & KelasKita & Office 365 \\
\hline 14 & 28 & 306 & 6 & 22 \\
\hline $2.45 \%$ & $4.90 \%$ & $53.50 \%$ & $1.05 \%$ & $3.85 \%$ \\
\hline
\end{tabular}




\begin{tabular}{lllll} 
Ruang Guru & Rumah Belajar & Schoology & Sekolahmu & Quipper \\
53 & 66 & 5 & 7 & 28 \\
$9.27 \%$ & $11.54 \%$ & $0.87 \%$ & $1.22 \%$ & $4.90 \%$ \\
Zenius & Using own app & Not using virtual classroom & \\
18 & 34 & 149 & \\
$3.15 \%$ & $5.94 \%$ & $26.05 \%$ & \\
\hline
\end{tabular}

Table 2 summarises various technologies used by teachers as pedagogical tools for conducting distance learning. Overall, there are some devices and applications commonly utilised in terms of facilitating learning to students remotely. Smartphones and laptops by far are the most popular devices preferred by $88.81 \%$ and $77.45 \%$ of teachers respectively. For online live teaching, over $56 \%$ of the teachers use WhatsApp video call and Zoom was used by around $21 \%$ of teachers. While other applications were used by less than $10 \%$ of teachers, there are over $35 \%$ of teachers do not teach live. Regarding applications for communicating with students, WhatsApp is the most popular one used by almost $100 \%$ of the teachers while in contrast, no one was operating Slack, and harnessing Line, Twitter, and WeChat was also uncommon. Email was used by almost $35 \%$ of teachers whilst there are mere less than $20 \%$ of teacher using FB Messenger and Instagram to get in touch with students. Finally, Google Classroom is the most popular application for conducting a lesson in the virtual environment. Other applications were merely used by less than $15 \%$ of teachers and there are over $25 \%$ of teachers do not using a virtual classroom platform.

It is not a surprise that the vast majority of teachers harness smartphones for conducting distance instructions since smartphones are the most popular mobile device used in Indonesia. The latest survey by Kemp (2020) reported that $94 \%$ of the adult population in Indonesia owned at least a smartphone whilst $66 \%$ of them have laptop or desktop computers and the tablet device handed by $23 \%$ of the adult population. The total population of Indonesia nowadays is 272.1 million people. However, from this finding could be draw a conclusion that smartphones are considerable for conducting distance learning programmes in K-12 setting. Unfortunately, few studies working on the use of smartphones as tool for distance education and the existing studies mostly work with university students. Although harnessing smartphones for remote learning in higher education context is also relatively a new practice, it has been proven that the uses improve student's learning engagements and facilitate students-lecturers communication (Vazquez-Cano, 2014; Tuncay, 2016). Smartphones support real-time distance learning and synchronous collaboration between students and lecturers (Lee, 2012). Hence, smartphones as smart pedagogical tools promote ubiquitous learning environment (Shin et al., 2011). Maximising the use of smartphones in this case could be also a solution of the traditional distance learning based on computers that not fully suitable due to the lack of laptop and desktop computers (Gopalan et al., 2011).

Interestingly, WhatsApp application used by over one half of the teachers for synchronous teachings while the other applications are less popular with the exception of Zoom. Additionally, WhatsApp is also the main medium for distance teachers-students communications. This finding reveals that WhatsApp is potential for facilitating teaching and learning at a distance. Reasons that WhatsApp is highly acceptable for distance learning owing to the great user friendliness, accessibility, and cost effectiveness (Nawaila \& Bicen, 2018; Singh et al., 2018). Some studies have confirmed the potentiality in different ways based on the features such as WhatsApp chat (Çetinkaya \& Sütçü, 2018; Ahmed, 2019) and WhatsApp group (Annamalai, 2019; Rahmadi, 2020) for supporting effective learning and instruction activities. Zoom and the other conferencing tools recently gains more and more popularity in the midst of COVID-19 outbreak as a medium for having synchronous online classrooms. Another important point to note is that the teachers have also attempted to use various social media for distance learning. Over one-third of teachers, however, do not conduct an online live teaching. This is quite reasonable owing to the teachers do not get used to a synchronous teaching facilitated by new media, limited broadband or mobile bandwidth, and limited resources of students. This a new way of teaching is highly challenging both for teachers and students (May et al., 2015) that require different teaching and learning strategies compared to face-to-face live instructions (Safei et al., 2011).

Teachers use a variety of applications for managing virtual classroom environments which the majority utilise Google Classroom. This could be the case as a matter of fact that Google Classroom is a free and easy- 
to-use learning management system (Heggart \& Yoo, 2018; Rozak \& Albantani, 2018). The platform in the view of usability is useful with regard to the understandability, attractiveness, and operability (Ventayen et al., 2018). Other virtual classroom platforms are less popular while some teachers develop and use their own application. Developing own platform is possible by using learning management systems such as Moodle, Chamilo, and Blackboard; however, it looks more complicated rather than simply adopting Google Classroom. In addition to the virtual classroom concern, around a quarter of teachers do not teach in a virtual classroom environment. Integrating a learning management system into teaching practices require not only specific technical knowledge but new pedagogical knowledge as well (Anderson \& Dron, 2017; Adnan et al., 2017; Ouadoud et al., 2018). The pedagogical nature and technical issues might decrease teachers' intention to take the opportunity in using a system for managing virtual learning (Walker et al., 2016). Hence, developing teachers' specific technological and pedagogical knowledge is of importance before integrating certain technologies for learning.

Reflecting on the various technologies chosen by teachers, it seems that the teachers tend to use technologies for remote instruction that already they used for daily life. For instance, smartphones and the WhatsApp application that been widely used in everyday activities are also used by teachers for online live teaching and communicating with students from their homes. Another important point to reflect is that global products are more likely chosen by teachers for managing virtual classrooms rather than the local ones. As an example, Google Classroom is much preferable than made-in-Indonesia applications such as Rumah Belajar, Ruang Guru, KelasKita, and Sekolahmu, just to name a few. Apart from the tendencies, it looks normal that other teachers integrate other technologies suitable for themselves since there is no one-size-fits-all in distance learning (Doucet et al., 2020), different subjects and age groups require different approaches to distance learning. Hence, trusting the teachers to run as convenient distance instruction as possible in their version at this critical time may be appropriate for the meantime. For the future, the trends identified in this study should be taken into account wisely to make a technology integration policy for distance learning practices in school environments.

\section{The Process of Distance Learning Conducted by Teachers}

Issues described in the distance learning processes include learning activities, tasks, and resources that were given to students and used by teachers as a means of teaching remotely. The learning activities were categorised based on the revised version of Bloom's taxonomy cognitive domain that includes remembering, understanding, applying, analysing, evaluating, and creating (Anderson et al., 2001). In addition, learning theories of behaviorism, cognitivism, constructivism, and connectivism applied to classify the task types. To be more detail, the tasks and related learning theories include: working on multiple-choice and essay tests assigned by and collected to teachers (behaviorism), reading textbooks then write a summary (cognitivism), discussing learning materials with peers or parents then conclude the discussion by writing a summary or drawing a picture such as concept maps and infographics (constructivism) and creating a particular product from the learning material then share it to peers or other people through various digital media (connectivism). Several learning resources used during remote learning such as textbooks, environments, peers, parents, and online resources outlined as well in the following table.

Table 3. The Process of Distance Learning Conducted by Teachers

\begin{tabular}{llllll}
\hline Activities & & & & & \\
Remembering & Understanding & Applying & Analysing & Evaluating & Creating \\
109 & 455 & 233 & 304 & 285 & 307 \\
$19.06 \%$ & $79.55 \%$ & $40.73 \%$ & $53.15 \%$ & $49.83 \%$ & $53.67 \%$ \\
\hline Tasks & & & & & \\
Doing & Reading & Discussing & Creating & & \\
homework & textbooks & materials & products & \\
470 & 286 & 162 & 234 & \\
$82.17 \%$ & $50.00 \%$ & $28.32 \%$ & $40.91 \%$ & \\
\hline
\end{tabular}




\begin{tabular}{lllll}
\hline Resources & & & & \\
Textbooks & Environments & Peers & Parents & Online resources \\
476 & 263 & 169 & 267 & 464 \\
$83.22 \%$ & $45.98 \%$ & $29.55 \%$ & $46.68 \%$ & $81.12 \%$ \\
\hline
\end{tabular}

Table 3 reveals the distance learning processes conducted by teachers to their students. All in all, there are typical activities, tasks, and resources frequently used for learning at a distance. Almost $80 \%$ of activities are about understanding and it four times higher than those of remembering. Surprisingly, the activities of analysing and creating something from the learning material have slightly a shared number of around 53\%, and the two other activities are recorded fewer than $50 \%$. It is clear from this data that the vast majority of teachers give a task to students for doing homework reached over $80 \%$. Conversely, discussing materials seems less common tasks during the distance learning that merely under $30 \%$ of teachers give this task to students. While $50 \%$ of teachers ask students to read textbooks, the students were asked to create products by around $40 \%$ of teachers. Concerning the learning resources, textbooks and resources on the Internet by far are the most frequent resources used by teachers reaching over $80 \%$. Around $45 \%$ of teachers harness environments and parents as resources for learning whilst peers were only utilised by around $30 \%$ of teachers.

Understanding learning material, as the main students' learning activities facilitated by their teachers from a distance, implies that the learning process runs on the lower order thinking skills. This is a general problem in Indonesia teaching and learning processes regardless of face-to-face or distance learning mode, and in particular within the implementation of a new curriculum in Indonesia called Kurrikulum 2013 (Alinurdin \& Rahmadi, 2018). Teachers' previous knowledge and beliefs about higher-order thinking skills assumed as principal factors affecting the level of pedagogical practices in the classroom (Kusumastuti et al., 2019). Although around half of the teachers have undergone activities based on higher-order thinking skills, it is pivotal to encourage all teachers for moving forward from the lower-level ones.

As doing homework is the common day-to-day student's task, it seems that the majority of teachers are teaching remotely in a behaviorism way. The teachers are more likely to give test-based assignments rather than activity-based assignments, which can stimulate students to think, construct, or create a certain product from the learning materials. Homework behavior was just like a tradition in education around the world that exists for some reason. It is true that homework plays an important role for reinforcement of school learning and for development of personal responsibility (Xu \& Yuan, 2003; Corno \& Xu, 2004); however, using homework as main distance learning task could be stressful than meaningful not only for students but also for parents during the COVID-19 outbreak (Suldo et al., 2008; Xu, 2011; Galloway et al., 2013; Clausen et al., 2020). Looking at homework differently might be a solution by actively involving social and cultural aspects that increase a sense of community between students, peers, parents, and teachers in their social environments (Corno, 2000). Hence, for example, constructing and discussing learning material with peers or parents as well as creating and sharing a product to the community appeals as more fruitful tasks during the distance learning.

The majority of teachers rely on textbooks and other resources on the Internet as distance learning resources inline with the fact that the majority of distance learning tasks are more about doing homework rather than assigning other tasks involved with their peers, parents, and environments around them. Likewise, this is also a common case in Indonesia's face-to-face teaching practices that the teachers mostly use textbooks as the main learning resources. Textbooks have been widely used for teaching in the early decade of education and are indeed highly important for basic learning resources (Davey, 1988). Nowadays, more appropriate use of paper-based textbooks should be combined or integrated with other electronic or digital resources (McDonald, 2016). At the time of social and physical distancing, encouraging active interaction among students, parents, and their learning environments is valuable for the resource of learning. Additionally, having a virtual meeting with peers might be beneficial to support each other about their study progress.

Reflecting on what teachers have been done with the distance learning processes facilitated by various technologies opens up the possibility to predict their technology integration levels. It can be said that the teachers stand on an enhancement level of technology integration thus yet integrate technology as a 
transformation of learning. Based on the SAMR model of technology integration (Puentedura, 2006), the teachers integrate technology mainly for substituting and augmenting a distance learning process instead of modifying and redefining learning. In other words, framing from Prensky (2005), the teachers remain dabbling and doing old things in old ways although multiple smart technologies already in their hands. Hence, measuring within the technology integration matrix (Florida Center for Instructional Technology, 2019), it appears that the teachers are in between adoption and adaptation level since they use modern technologies in conventional ways of teaching. Furthermore, looking from the TPACK perspective (Koehler \& Mishra, 2005; Mishra \& Koehler, 2006), the teachers do not yet integrate technology in active relation to pedagogy and content. However, this teacher's experience in initiating the integration of technology for enhancing learning could be valuable to move forward into the transformation stage. Perhaps encouraging professional developments either for pre-service or in-service teachers with a focus on educational technology issues will result in a higher level of technology integration in the future.

\section{Teachers' Distance Learning Adoption Levels}

The teachers' distance learning adoption levels address various levels of teachers in adopting remote learning to their hands after a sudden implementation of the working-from-home policy. Adopted from the Rogers's innovations adoption curve (1962), there are five levels of adoption used in this study and described as follows: 1) innovators = teachers are ready for distance learning before the implementation of working-from-home policy; 2) early adopters = teachers immediately prepare for distance learning when the working-from-home policy have been implemented; 3) early majority = teachers start to prepare for distance learning when the working-from-home policy have been implemented because seeing other teachers were preparing for it; 4) late majority = teachers start to prepare for distance learning when the working-from-home policy have been implemented after seeing that other teachers are able to teach remotely from home; 5) laggards $=$ teachers do not prepare for distance learning although the working-from-home policy have been implemented and think to prepare it later. The teacher's adoption levels of distance learning are illustrated in the figure below.

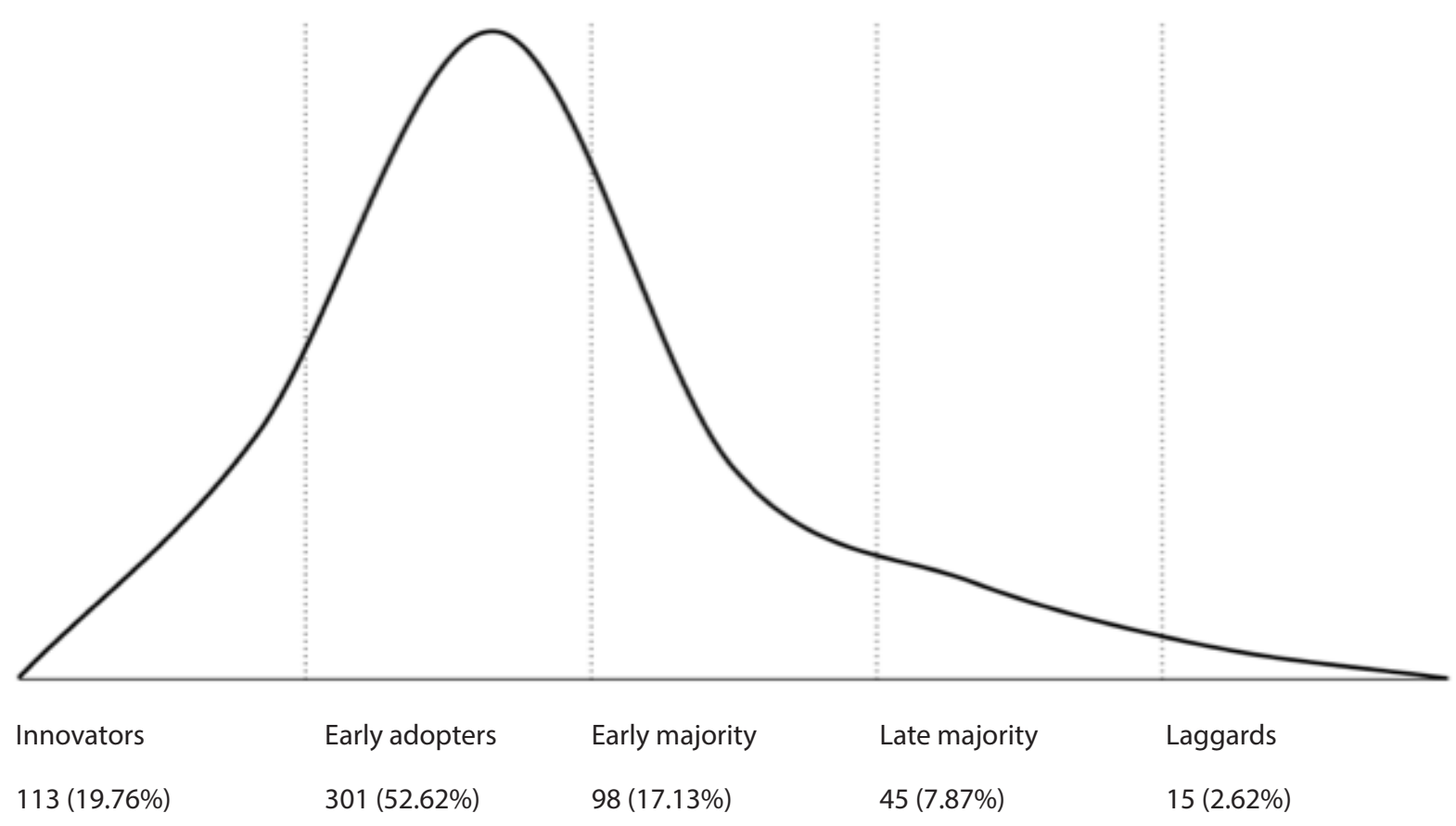

Figure 1. Teachers' Distance Learning Adoption Level Based on the Adoption Curve (Rogers, 1962)

Figure 1 illustrates the teachers' distance learning adoption levels. In general, the majority of teachers defined themselves as early adopters of distance learning. More than half of teachers fall into the category whilst the figure for the early and late majority reached $17.13 \%$ and $7.87 \%$ respectively. The number of innovators is 
almost $20 \%$ and the figure for laggards less than $3 \%$. The curve is fairly different from the origin theory since conceptually there should be $2.5 \%$ of innovators, $13.5 \%$ of early adopters, $34 \%$ of early majority, $34 \%$ of late majority, and 16\% of laggards (Rogers, 1962). While in this case the early adopters much higher than the early and late majority, and there are more innovators than laggards.

The teachers' adoption level in this study is consistent with the study of Aldunate \& Nussbaum (2013) revealed that most teachers in their study about teacher's adoption of technology fall into the category of early adopters and followed by innovators. Teachers who are early technology adopters have a significant time in incorporating educational technology and they are more likely to adopt new technology to their teaching practices. Another study, particularly about technology adoption for learning, is also shown that teachers have substantially adopted technology at a moderate level (Kotrlik \& Redmann, 2009; Redmann \& Kotrlik, 2009), however, the technology have not integrated adequately. This sounds interesting since have been adopting technology does not automatically mean that teachers have been utilised the technology in appropriate ways for teaching and learning purposes.

Reflecting on the teachers' distance learning adoption levels, it is great that most teachers have immediately prepared for distance learning when the working-from-home policy has been implemented. Surprisingly, one-fifth of the teachers are innovators and there are merely a few teachers who are laggards. Thus it can be said that so far the teachers are agile in adopting distance learning during the COVID-19 crisis. Although further investigation is still needed to clarify whether the teachers adopting and practicing distance learning appropriately or vise versa, this fact is an optimistic signal to effectively adapt and adopt remote instruction to the formal school environments in the future.

\section{CONCLUSION}

The present study has given a description, discussion and reflection of teachers' technology integration and distance learning adoption after the working-from-home policy has been implemented as a precaution towards the further transmission of the COVID-19 in Indonesia. This study set out to investigate technology used by teachers as tools for distance learning, the process of distance learning conducted by teachers, and teachers' distance learning adoption levels. The results of this investigation reveal that teachers tend to use devices and applications for remote instruction that already they used for daily life, and global applications are more likely chosen by teachers for managing virtual classrooms rather than the local ones. The teachers stand on an enhancement level of technology integration thus yet integrate technology as a transformation of learning. Most teachers have immediately prepared for distance learning when the working-from-home policy has been implemented so that they can be categorised as early adopters of distance learning.

The evidence from this study suggests that trusting teachers to conduct distance learning with technologies they are familiar with is essential during the critical time. Furthermore, the trends identified in this study should be taken into account seriously to draw a proper technology integration policy for distance learning practices in school environments. Teacher's experience in initiating the integration of technology for enhancing learning is rewarding to move forward into the transformation stage by professional developments either for pre-service or in-service teachers with particular interest concerning educational technology. One of the ideas might be TPACK-based professional development in various modes of teacher education programmes (Rahmadi et al., 2020). The teachers' agility in adopting distance learning during the COVID-19 crisis raises an optimistic signal to effectively adapt and adopt remote instruction to the formal school environments in the future.

The empirical findings in this study provide a new understanding of teachers' technology integration and distance learning adoption amidst the unprecedented global impacts of the COVID-19. However, the current study has focused on examining teachers' technology integration and distance learning adoption in one country regardless of teaching subjects and school levels. What is now needed is a cross-national study involving multiple countries on a specific subject of teaching and level of school due to the different subjects and student groups require different approaches to remote learning. Otherwise comparing among teaching subjects could be a further comparative study. 
Acknowledgements: The author would like to acknowledge teachers who have voluntarily participated in this study.

\section{BIODATA and CONTACT ADDRESSES of AUTHOR}

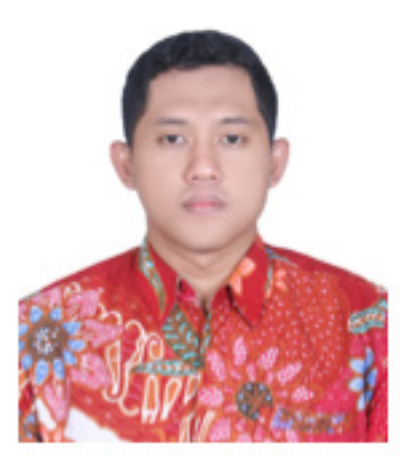

Imam Fitri RAHMADI is a lecturer at Universitas Pamulang Indonesia and a PhD student at the Department of STEM Education, Linz School of Education, Johannes Kepler Universität Linz Austria. Educational technology integration into learning and instruction is his overall research interest. In his $\mathrm{PhD}$ research, he explores the potential of user-generated microgames for supporting STEAM learning. He is an awardee of the Indonesia-Austria Scholarship Programme (IASP), a joint scholarship between the Indonesian Ministry of Education and Culture (KEMDIKBUD) and Austria's Agency for Education and Internationalisation (OeAD-GmbH) in cooperation with ASEAN European Academic University Network (ASEA-UNINET).

Imam Fitri RAHMADI

Department of Civic Education, Faculty of Teacher Training and Education

Address: Universitas Pamulang, 15417, Tangerang Selatan, Indonesia

Phone: +62217412566

E-mail: imamrahmadi@unpam.ac.id

\section{REFERENCES}

Adegbenro, J. B., \& Olugbara, O. O. (2019). Investigating Computer Application Technology Teachers' Procedural Knowledge and Pedagogical Practices in ICT- Enhanced Classrooms. Africa Education Review, 16(1), 1-18. Scopus. https://doi.org/10.1080/18146627.2017.1394516

Adewara, A. J., \& Lawal, O. (2015). New technologies and science teachers education within the context of distance learning: A case study for the university of Lagos. Turkish Online Journal of Distance Education, 16(3), 48-60. Scopus.

Adnan, M., Kalelioglu, F., \& Gulbahar, Y. (2017). Assessment of a Multinational Online Faculty Development Program on Online Teaching: Reflections of Candidate E-Tutors. Turkish Online Journal of Distance Education, 18(1), 22-22. https://doi.org/10.17718/tojde.285708

Ahmed, S. T. S. (2019). Chat and Learn: Effectiveness of Using WhatsApp as a Pedagogical Tool to Enhance EFL Learners Reading and Writing Skills. International Journal of English Language and Literature Studies, 8(2), 61-68. https://doi.org/10.18488/journal.23.2019.82.61.68

Aldunate, R., \& Nussbaum, M. (2013). Teacher adoption of technology. Computers in Human Behavior, 29(3), 519-524. https://doi.org/10.1016/j.chb.2012.10.017

Alinurdin, \& Rahmadi, I. F. (2018). Implementasi Kurikulum 2013 pada Sekolah Menengah Pertama di Kota Tangerang Selatan. Jurnal Pendidikan Kewarganegaraan, 5(2), 117. https://doi.org/10.32493/ jpkn.v5i2.y2018.p117-136

Anderson, L. W., Krathwohl, D. R., \& Bloom, B. S. (2001). A taxonomy for learning, teaching, and assessing: $A$ revision of Bloom's taxonomy of educational objectives. Longman. https://books.google.at/ books?id=JPkXAQAAMAAJ

Anderson, T., \& Dron, J. (2017). Integrating learning management and social networking systems. Italian Journal of Educational Technology, 25(3), 5-19.

Annamalai, N. (2019). Using WhatsApp to Extend Learning in a Blended Classroom Environment. Teaching English with Technology, 19(1), 3-20. 
Betrus, A. K. (2008). Resources. In A. Januszewski \& M. Molenda (Eds.), Educational technology: A definition with commentary (pp. 213-240). Routledge.

Budiman, A., \& Ngadiso. (2018). EFL teacher's belief and practice on integrating information and communication technology (ICT) in the classroom. Asian EFL Journal, 20(4), 7-22. Scopus.

Cassidy, S., \& Lane, C. (1994). Planned Change and the Adoption of Distance Learning. ED, Education at a Distance, 8(8), 11-19.

Çetinkaya, L., \& Sütçü, S. S. (2018). The effects of Facebook and WhatsApp on success in English vocabulary instruction. Journal of Computer Assisted Learning, 34(5), 504-514. https://doi.org/10.1111/ jcal.12255

Clausen, J. M., Bunte, B., \& Robertson, E. T. (2020). Professional Development to Improve Communication and Reduce the Homework Gap in Grades 7-12 during COVID-19 Transition to Remote Learning. Journal of Technology and Teacher Education, 28(2), 443-451.

Corno, L. (2000). Looking at Homework Differently. The Elementary School Journal, 100(5), 529-548. https://doi.org/10.1086/499654

Corno, L., \& Xu, J. (2004). Homework as the Job of Childhood. Theory Into Practice, 43(3), 227-233. https://doi.org/10.1207/s15430421 tip4303_9

Cox, S., \& Graham, C. R. (2009). Diagramming TPACK in Practice: Using an Elaborated Model of the TPACK Framework to Analyze and Depict Teacher Knowledge. Tech Trends, 53(5), 60-69. https:// doi.org/10.1007/s11528-009-0327-1

Cubeles, A., \& Riu, D. (2016). Teachers' use of technology in the university classroom. 02-04-November-2016, 671-676. Scopus. https://doi.org/10.1145/3012430.3012591

Davey, B. (1988). How Do Classroom Teachers Use Their Textbooks? Journal of Reading, 31(4), 340-345. JSTOR.

Davies, R. S., \& West, R. E. (2014). Technology Integration in Schools. In J. M. Spector, M. D. Merrill, J. Elen, \& M. J. Bishop (Eds.), Handbook of Research on Educational Communications and Technology (pp. 841-853). Springer New York. https://doi.org/10.1007/978-1-4614-3185-5_68

Dees, L., LaCour, M., \& Lockwood, R. (2017). Exploring teachers' use of tablet technology in the classroom: Tools for motivating at-risk learners. International Journal of Technologies in Learning, 24(2), 1-9. Scopus. https://doi.org/10.18848/2327-0144/CGP/v24i02/1-9

Dillinger, L. S. (2000). Interactive learning at a distance: Technology integration training for pre-service and in-service teachers. International Journal of Continuing Engineering Education and Life-Long Learning, 10(1-4), 189-201. Scopus.

Doucet, A., Netolicky, D., Timmers, K., \& Tuscano, F. J. (2020). Thinking about Pedagogy in an Unfolding Pandemic: An Independent Report on Approaches to Distance Learning During COVID 19 School Closures (Vol. 2).

Florida Center for Instructional Technology. (2019). The Technology Integration Matrix: Third Edition. TIM. https://fcit.usf.edu/matrix/matrix/

Fuentes, J. L., \& Albertos, J. (2017). Tablets in the classroom: Perceptions of Spanish teachers as agents of change in pedagogy and technology use. Cadmo, 25(1), 81-100. Scopus. https://doi.org/10.3280/ CAD2017-001009

Gabby, S., Avargil, S., Herscovitz, O., \& Dori, Y. J. (2017). The Case of Middle and High School Chemistry Teachers Implementing Technology: Using the Concerns-based Adoption Model to Assess Change Processes. Chemistry Education Research and Practice, 18(1), 214-232. https://doi.org/10.1039/ C6RP00193A 
Galloway, M., Conner, J., \& Pope, D. (2013). Nonacademic Effects of Homework in Privileged, HighPerforming High Schools. The Journal of Experimental Education, 81(4), 490-510. https://doi.org /10.1080/00220973.2012.745469

Gopalan, A., Karavanis, S., Payne, T., \& Sloman, M. (2011). Smartphone Based E-learning. Proceedings of the 3rd International Conference on Computer Supported Education, 161-170. https://doi. org/10.5220/0003334901610170

Hall, B., \& Khan, B. (2003). Adoption of New Technology (No. w9730). National Bureau of Economic Research. https://doi.org/10.3386/w9730

Heggart, K., \& Yoo, J. (2018). Getting the Most from Google Classroom: A Pedagogical Framework for Tertiary Educators. Australian Journal of Teacher Education, 43(3), 140-153. https://doi. org/10.14221/ajte.2018v43n3.9

Holcomb, Z. C. (2016). Fundamentals of Descriptive Statistics. Routledge.

Humbert, M. (2007). Adoption of Blended Learning by Faculty: An Exploratory Analysis. In M. K. McCuddy, H. van den Bosch, Wm. B. Martz, A. V. Matveev, \& K. O. Morse (Eds.), The Challenges of Educating People to Lead in a Challenging World (pp. 423-436). Springer Netherlands. https:// doi.org/10.1007/978-1-4020-5612-3_21

Kemp, S. (2020). Digital 2020: Indonesia. DataReportal - Global Digital Insights. https://datareportal.com/ reports/digital-2020-indonesia

Kiper, A., \& Tercan, S. S. (2012). The usage of information technologies in classroom environment among primary school teachers and their perception on in-service training programs on it (sample of Sakarya). Turkish Online Journal of Educational Technology, 11(3), 386-392. Scopus.

Kisanga, D., \& Ireson, G. (2015). Barriers and strategies on adoption of e-learning in Tanzanian higher learning institutions: Lessons for adopters. International Journal of Education and Development Using ICT, 11(2), 126-137.

Koehler, M. J., \& Mishra, P. (2005). What Happens When Teachers Design Educational Technology? The Development of Technological Pedagogical Content Knowledge. Journal of Educational Computing Research, 32(2), 131-152. https://doi.org/10.2190/0EW7-01WB-BKHL-QDYV

Koehler, M. J., Mishra, P., \& Cain, W. (2013). What is Technological Pedagogical Content Knowledge (TPACK)? Journal of Education, 193(3), 13-19. https://doi.org/10.1177/002205741319300303

Koehler, M., \& Mishra, P. (2009). What is Technological Pedagogical Content Knowledge (TPACK)? Contemporary Issues in Technology and Teacher Education, 9(1), 60-70.

Kotrlik, J. W., \& Redmann, D. H. (2009). Technology Adoption for Use in Instruction by Secondary Technology Education Teachers. Journal of Technology Education, 21(1), 44-59. https://doi. org/10.21061/jte.v21i1.a.3

Kusumastuti, I., Fauziati, E., \& Marmanto, S. (2019). Revealing Teachers' Beliefs of Higher Order Thinking Skills in Teaching Reading at Junior High School. English Language and Literature International Conference (ELLiC) Proceedings, 3(0), 155-162.

Lee, J. H. (2012). Real-Time Mobile Distance Learning System for Smartphone. In Y. Luo (Ed.), Cooperative Design, Visualization, and Engineering (Vol. 7467, pp. 24-32). Springer Berlin Heidelberg. https:// doi.org/10.1007/978-3-642-32609-7_3

Levin, K. A. (2006). Study design III: Cross-sectional studies. Evidence-Based Dentistry, 7(1), 24-25. https:// doi.org/10.1038/sj.ebd.6400375

Martinez-Cola, M., with, English, R., Min, J., Peraza, J., Tambah, J., \& Yebuah, C. (2018). When Pedagogy Is Painful: Teaching in Tumultuous Times. Teaching Sociology, 46(2), 97-111. https://doi. org/10.1177/0092055X17754120 
May, D., Sadiki, A., Pleul, C., \& Tekkaya, A. E. (2015). Teaching and learning globally connected using live online classes for preparing international engineering students for transnational collaboration and for studying in Germany. Proceedings of 2015 12th International Conference on Remote Engineering and Virtual Instrumentation (REV), 118-126. https://doi.org/10.1109/REV.2015.7087275

McDonald, C. V. (2016). Evaluating Junior Secondary Science Textbook Usage in Australian Schools. Research in Science Education, 46(4), 481-509. https://doi.org/10.1007/s11165-015-9468-8

Merç, A. (2015). Using technology in the classroom: A study with turkish pre-service EFL teachers. Turkish Online Journal of Educational Technology, 14(2), 229-240. Scopus.

Mishra, P., \& Koehler, M. J. (2006). Technological pedagogical content knowledge: A framework for teacher knowledge. Teachers College Record, 108(6), 1017.

Nawaila, M. B., \& Bicen, H. (2018). WhatsApp as a tool for distance learning. PONTE International Scientific Researchs Journal, 74(1), 1-26. https://doi.org/10.21506/j.ponte.2018.1.36

Okazaki, S., \& Renda dos Santos, L. M. (2012). Understanding e-learning adoption in Brazil: Major determinants and gender effects. The International Review of Research in Open and Distributed Learning, 13(4), 91. https://doi.org/10.19173/irrodl.v13i4.1266

Ouadoud, M., Chkouri, M. Y., \& Nejjari, A. (2018). Learning Management System and the Underlying Learning Theories: Towards a new Modeling of an LMS. International Journal of Information Science and Technology, 2(1), 25-33.

Pange, J., Leontitsis, A., \& Siogka, E. (2004). Are the Greek Preschool teachers able to use distance learning technologies? 672-673. Scopus. https://www.scopus.com/inward/record.uri?eid=2-s2.014544280621\&partnerID=40\&md5=f8a68753b294097d9d00dfe468bd9181

Pareja Roblin, N., Tondeur, J., Voogt, J., Bruggeman, B., Mathieu, G., \& van Braak, J. (2018). Practical considerations informing teachers' technology integration decisions: The case of tablet PCs. Technology, Pedagogy and Education, 27(2), 165-181. https://doi.org/10.1080/147593 9X.2017.1414714

Perea, G. (2016). The teacher and the technologies used in the classroom. 304-309. Scopus. https://www. scopus.com/inward/record.uri?eid=2-s2.0-85015277118\&partnerID=40\&md5=bc62896cfb767 00dbaaac6ebf5f50f95

Porter, W. W., Graham, C. R., Spring, K. A., \& Welch, K. R. (2014). Blended learning in higher education: Institutional adoption and implementation. Computers \& Education, 75, 185-195. https://doi. org/10.1016/j.compedu.2014.02.011

Prensky, M. (2005, December 2). Shaping Tech for the Classroom: 21st-century schools need 21st-century technology. Edutopia. https://www.edutopia.org/adopt-and-adapt-shaping-tech-for-classroom

Puentedura, R. R. (2006). Transformation, Technology, and Education. Hippasus.Com. http://hippasus.com/ resources/ttel

Rahmadi, I. F. (2020). WhatsApp Group for Teaching and Learning in Indonesian Higher Education: What's Up? International Journal of Interactive Mobile Technologies (IJIM), 14(13), 150-160. https://doi. org/10.3991/ijim.v14i13.14121Rahmadi, I. F., Hayati, E., \& Nursyifa, A. (2020). Comparing Pre-service Civic Education Teachers' TPACK Confidence Across Course Modes. Research in Social Sciences and Technology, 5(2), 113-133. https://doi.org/10.46303/ressat.05.02.7

Redmann, D. H., \& Kotrlik, J. W. (2009). Family and Consumer Sciences Teachers' Adoption of Technology for Use in Secondary Classrooms. Journal of Family \& Consumer Sciences Education, 27(1), 29-45.

Rosanda, V., \& Starcic, A. I. (2019). A review of social robots in classrooms: Emerging educational technology and teacher education. Education and Self Development, 14(3), 93-106. Scopus. https://doi. org/10.26907/esd14.3.09 
Rozak, Abd., \& Albantani, A. M. (2018). Desain Perkuliahan Bahasa Arab Melalui Google Classroom. Arabiyat: Jurnal Pendidikan Bahasa Arab Dan Kebahasaaraban, 5(1). https://doi.org/10.15408/a. v5i1.7481

Ruggiero, D., \& Mong, C. J. (2015). The teacher technology integration experience: Practice and reflection in the classroom. Journal of Information Technology Education: Research, 14(2015), 161-178. Scopus.

Safei, S., Amin, M. A. M., Rose, A. N. M., \& Rahman, M. N. A. (2011). Instant e-teaching framework model for live online teaching. International Journal of Computer Science Issues, 8(2), 84-91.

Sarrab, M. (2013). Exploring Major Challenges and Benefits of M-learning Adoption. British Journal of Applied Science \& Technology, 3(4), 826-839. https://doi.org/10.9734/BJAST/2013/3766

Sepasgozar, S., \& Davis, S. (2018). Construction Technology Adoption Cube: An Investigation on Process, Factors, Barriers, Drivers and Decision Makers Using NVivo and AHP Analysis. Buildings, 8(6), 74. https://doi.org/10.3390/buildings8060074

Shin, D.-H., Shin, Y.-J., Choo, H., \& Beom, K. (2011). Smartphones as smart pedagogical tools: Implications for smartphones as u-learning devices. Computers in Human Behavior, 27(6), 2207-2214. https:// doi.org/10.1016/j.chb.2011.06.017

Singh, H. K. D., Lim, T. M., Woo, T. K., \& Fadzil, M. (2018). Mobile Learning Support to Distance Learners: Using WhatsApp Messenger. In K. C. Li, K. S. Yuen, \& B. T. M. Wong (Eds.), Innovations in Open and Flexible Education (pp. 109-119). Springer Singapore. https://doi.org/10.1007/978981-10-7995-5_10

Smith, H. E., Stair, K. S., Blackburn, J. J., \& Easley, M. (2018). Is There an App for That?: Describing Smartphone Availability and Educational Technology Adoption Level of Louisiana SchoolBased Agricultural Educators. Journal of Agricultural Education, 59(1), 238-254. https://doi. org/10.5032/jae.2018.01238

Song, M. J. (2018). Learning to teach 3D printing in schools: How do teachers in Korea prepare to integrate 3D printing technology into classrooms? Educational Media International, 55(3), 183-198. Scopus. https://doi.org/10.1080/09523987.2018.1512448

Straub,E.T.(2009). UnderstandingTechnologyAdoption:TheoryandFutureDirectionsforInformal Learning. Review of Educational Research, 79(2), 625-649. https://doi.org/10.3102/0034654308325896

Sugar, W., Crawley, F., \& Fine, B. (2004). Examining Teachers' Decisions To Adopt New Technology. Journal of Educational Technology \& Society, 7(4), 201-213. JSTOR.

Suldo, S. M., Shaunessy, E., \& Hardesty, R. (2008). Relationships among stress, coping, and mental health in high-achieving high school students. Psychology in the Schools, 45(4), 273-290. https://doi. org/10.1002/pits.20300

Tondeur, J., Devos, G., Van Houtte, M., van Braak, J., \& Valcke, M. (2009). Understanding structural and cultural school characteristics in relation to educational change: The case of ICT integration. Educational Studies, 35(2), 223-235. https://doi.org/10.1080/03055690902804349

Tuncay, N. (2016). Smartphones as tools for Distance Education. Journal of Educational and Instructional Studies in the World, 6(2), 20-29.

Vazquez-Cano, E. (2014). Mobile Distance Learning with Smartphones and Apps in Higher Education. Educational Sciences: Theory and Practice, 14(4), 1505-1520. https://doi.org/10.12738/ estp.2014.4.2012

Vecino, P. (2017). Integrating technology in Argentine classrooms: The case of a Buenos Aires teacher education school. In English Language Teaching in South America: Policy, Preparation and Practices (pp. 123-140). Scopus. https://doi.org/10.21832/KAMHI7975 
Ventayen, R. J. M., Estira, K. L. A., Guzman, M. J. D., Cabaluna, C. M., \& Espinosa, N. N. (2018). Usability Evaluation of Google Classroom: Basis for the Adaptation of GSuite E-Learning Platform. Asia Pacific Journal of Education, 5(1), 47-51.

Walker, D. S., Lindner, J. R., Murphrey, T. P., \& Dooley, K. (2016). Learning management system usage. Quarterly Review of Distance Education, 17(2), 41-50.

Wang, L. (2014). An examination of teachers' integration of web 2.0 technologies in secondary classrooms: A phenomenological study. 345-348. Scopus. https://www.scopus.com/inward/record.uri?eid=2s2.0-84906538778\&partnerID $=40 \& \mathrm{md} 5=201 \mathrm{f} 4144 \mathrm{dbff5} \mathrm{e} 1 \mathrm{aea} 203 \mathrm{fb} 8 \mathrm{cb} 012 \mathrm{ec} 6$

Wang, T. (2016). Overcoming teachers' concerns-Where are we in the harnessing of mobile technology in K-12 classrooms in Hong Kong? (Issue 9789811000256, p. 248). Scopus. https://doi.org/10.1007/978981-10-0027-0_14

Wang, X., \& Cheng, Z. (2020). Cross-Sectional Studies. Chest, 158(1), S65-S71. https://doi.org/10.1016/j. chest.2020.03.012

Xu, J. (2011). Homework Completion at the Secondary School Level: A Multilevel Analysis. The Journal of Educational Research, 104(3), 171-182. https://doi.org/10.1080/00220671003636752

Xu, J., \& Yuan, R. (2003). Doing homework: Listening to students,'parents,'and teachers' voices in one urban middle school community. School Community Journal, 13(2), 25-44.

Yu, S., Chen, I.-J., Yang, K.-F., Wang, T.-F., \& Yen, L.-L. (2007). A feasibility study on the adoption of e-learning for public health nurse continuing education in Taiwan. Nurse Education Today, 27(7), 755-761. https://doi.org/10.1016/j.nedt.2006.10.016 